\title{
A classroom is a classroom is a classroom?

\author{
A study of the affordance of \\ classroom design for classroom interaction
}

Anna Maria Hipkiss

In secondary schools, some teachers are fortunate enough to have their own classroom to which different groups of pupils come. Some classes have their own so called 'home classrooms' to which different teachers come to teach. Yet other teachers and pupils move around during the school day, meeting different classrooms with every school subject. When I started researching how classroom design and artefacts interact in teaching for my thesis, I was reminded of a classroom I shared with a colleague and a class many years ago. It was a science classroom that the pupils had furnished according to their wishes. They had wanted curtains in front of the fume cupboards, so that when they were not doing chemistry, they could 'hide that subject'. It was an aesthetic as well as pedagogical choice on their part. As these pupils were used to having discussions together as a group since primary school, they also chose to have circular tables for four to five pupils instead of that school's traditional threepupil laboratory benches. Following the design of the classroom, the teaching and learning that took place was based on the pupils' views and their experiences of how they learn best. 


\section{Background}

Why is teaching and learning interesting from the perspective of classrooms? Some teachers might say that they could 'do the job' just as well regardless of the classroom, and I am sure they could. Belief in one's setting, i.e. the classroom, and how this is used influence the teaching and learning activities that take place (Woolner 2015). At the same time, classrooms are reflections of society, enforcing rules and norms relevant to life outside school, and artefacts and access to different spaces within the classroom regulate behaviour (see for example Dahlberg \& Åsén 2012; Eriksson Bergström 2013; Hipkiss 2014 and Ravelli 2008). Furthermore, social rules and traditions for teachers as well as pupils are strong, so traditions around classroom designs are transferred to new classrooms when classes are moved to new buildings (Davidsson 2005), meaning that we do what we have always done and what we know works. At the same time, we must understand that how we read a classroom, a space, affects what we do with our language (Pennycook 2010). It is not so much the situation that affects what we say and do, but the space in which we interact that affects interaction, in Pennycook's view.

The design of a space affects how interaction evolves in teaching and learning (Kress \& Sidiropoulou 2008, 112). The interpersonal meaning (Halliday \& Matthiessen 2004) - how relations are created and maintained-consequently instantiates different pedagogic discourses (Bernstein 1999), depending on how furniture is arranged, what is visible on the walls, what is accessible, and how participants (are encouraged to) communicate (Björklid 2005; Hipkiss 2014 and Jewitt 2005). Along with how the space is arranged, how it is used affects pedagogic discourse and interpersonal relations (Lim 2011; Lim et al. 2012). Teachers who position themselves at the front of the classroom create a formal distance (built on tradition) from pupils, but by moving and changing positions, this distance can be reduced. Moving too much, however, might change their interpersonal relations. For example, when a teacher appears to be patrolling the classroom, pupils feel watched, and focus on the teacher's perceived expectations, even though the teacher's intention might 
merely have been to be available (Lim 2011). At the same time, how furniture is arranged in a classroom mirrors the teacher's ambitions and individual pedagogic discourse, for example, maintaining open social relations (Elm Fristorp 2012) or creating a supervisory space for teachers (Hipkiss 2014).

Along with affecting the pedagogic discourse, the design of a classroom affects pupils' abilities to acquire or learn the vertical discourse of the school (Jones 2008) - the subject-specific language use, in other words. This brings a second dimension to the study of classroom design: the language practices in the classroom. Interaction in the classroom between teachers and pupils entails cognitive and linguistic socialisation: pupils learn the subject disciplines and how they are realised linguistically in subject-specific language (also referred to as academic language) (Gibbons 2006). Subject-specific language is here characterised as subject-specific terminology, grammatical metaphors, and the passive voice. These characteristics are essential for acquiring both the concepts and the language of any subject (Gibbons 2006; Schleppegrell 2004). Studying interaction and its place in the classroom provides insights into how, when, and where pupils are invited or encouraged to use subject-specific language, and are consequently provided with affordances for meaning-making and knowledge-building. Subject-specific language is primarily realised as written texts (Christie 2005; Jones 2005). Interaction in the classroom must therefore allow pupils to develop their understanding of subject content and language in varying forms (Hipkiss 2014; Macnaught et al. 2013; Martin 2013; Maton 2014; Matruglio et al. 2013). Education should aim to provide opportunities for pupils to build knowledge cumulatively, as opposed to segmentally (Maton 2014). Cumulative knowledge-building entails new knowledge being added and integrated with existing knowledge, as can be seen from pupils' ability to contribute to discussions about content on an everyday basis, from their use of abstracted, generalised, subject-specific language, and their ability to see the connections temporally and spatially (Maton 2013).

In this essay, I discuss classroom design: how a school subject is understood from its design, what teaching and learning activities 
take place there, and how participants interact. The analysis of interaction will focus on when, where, and how subject-specific language is used.

\section{Method}

This essay is based on approximately 29 hours of observations and recordings of teaching in biology, chemistry, and home and consumer studies (HCS) in five classrooms in two lower secondary schools in Sweden. The recordings have been transcribed for linguistic analyses of the subject-specific language use, such as grammatical metaphors (Halliday \& Matthiessen 1994), and the use of the passive voice in the teachers' and pupils' interaction in relation to artefacts and classroom design (Hipkiss 2014). The research project was ethically approved and participants either agreed to be filmed or agreed to have their communication audio-recorded.

\section{Analysing classroom interaction}

The recorded lessons were analysed using the framework of curriculum macrogenres (or curriculum units) derived from genre theory (Christie 1995; Jones 2005; Martin \& Rose 2008), in order to identify teaching and learning activities. Curriculum macrogenres are staged, goal-oriented, and social processes (Christie 1995; Jones 2005) that consist of various steps and aim to achieve different educational goals, outlined in the curriculum and syllabus (Christie 2005, 22). Christie (ibid.) has described a prototypical linear curriculum macrogenre as being made up of three genres: curriculum initiation, which establishes the objectives of the lesson(s); curriculum collaboration, which often continues over several lessons, and involves independent work as well as group work or lectures; and curriculum closure, which finalises the work, for example as a presentation or a test.

Within the genres, there are clearly separated sections called stages (for example, orientation, repetition, follow-up). These are identified by their overarching purpose; for example, introducing a new subject, developing lab-work skills, or deepening pupils' understanding of 


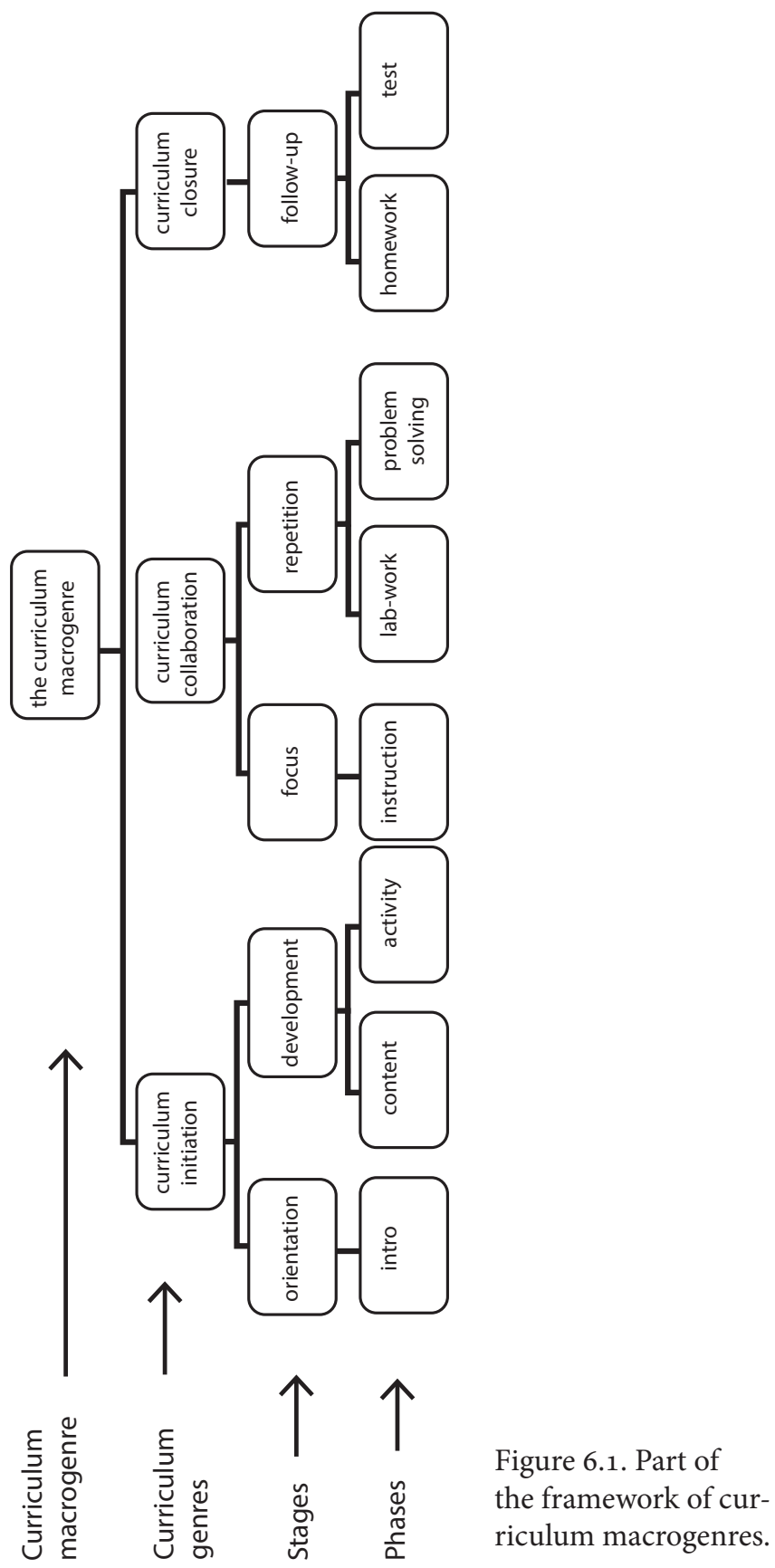


Total

\begin{tabular}{|c|c|c|c|c|c|c|c|}
\hline Classroom/school & $A: 1$ & $\mathrm{~B}: 2$ & $\mathrm{~B}: 2$ & $\mathrm{C}: 2$ & $\mathrm{D}: 2$ & $\mathrm{E}: 2$ & \\
\hline Subject & $\mathrm{HCS}$ & $\mathrm{HCS}$ & $\mathrm{HCS}$ & $\mathrm{Bl}$ & $\mathrm{BI}$ & $\mathrm{CH}$ & \\
\hline $\begin{array}{l}\text { Curriculum } \\
\text { macrogenre }\end{array}$ & Choices & Baking & Baking & Body & Body & Acids \& bases & \\
\hline Stages/Analysed phase & $6: 8$ & $6: 16$ & $3: 12$ & $7: 19$ & $9: 29$ & $10: 44$ & $37: 128$ \\
\hline \multicolumn{8}{|l|}{ Communicative pattern } \\
\hline Teacher monologue & 4 & 8 & 7 & 13 & 9 & 23 & 64 \\
\hline Pupil monologue & 1 & & & & & & 1 \\
\hline Teacher IRF & & 5 & & & 14 & 10 & 29 \\
\hline Pupil IRF & & & & & & 2 & 2 \\
\hline Dialogue & & & & 1 & 1 & & 2 \\
\hline Participatory exchange & 1 & 3 & 4 & 4 & 4 & 9 & 25 \\
\hline Other & & & 1 & 1 & 2 & & 4 \\
\hline
\end{tabular}

Table 6.1. Summary of data by classroom, subject (HCS=home \& consumer studies, $\mathrm{BI}=$ biology, $\mathrm{CH}=$ chemistry), macrogenre, stage, phase, and communicative pattern (Hipkiss 2014).

the subject by reading on their own. These stages, in turn, consist of phases (for example, introduction, setting up, homework follow-up, lab work), which are identified by communicative patterns (Gibbons 2006) such as teacher monologue, teacher IRF (initiation, response, feedback), pupil IRF, participatory exchange, and dialogue (Fig. 6.1).

There are several similarities between the analytical process in this study and the analytical processes in studies by Rocksén and Kilhamn et al. (chapter 9 and 8 in this volume). In all three studies, interaction through participation and subject-specificity form the basis for coding the material, and our analyses move between parts and whole, although with different focuses. The analyses of the observed lessons, genres, stages, phases, and communicative patterns are thus summarised in Table 6.1. The analysis did not extend to temporal aspects, such as how long a phase is or how long a participant's turn lasts. Plainly, communication in the classrooms was for the most part controlled by the teachers. Of 128 phases, 93 were either teacher monologues or teacher IRF. Pupil-controlled communication occurred in 31 of the 128 phases (pupil IRF and participatory exchanges) and took place during work in kitchens, lab work, or work from the textbook. These 
communicative patterns corresponded to the design in the classrooms, which are presented in the sections below. A description is also given of where and how subject-specific language use occurred. Here, the use of the term subject-specific language is restricted to indicators such as grammatical metaphors and processes (Halliday \& Matthiessen 2004). These lexicogrammatical resources are at the abstract end of the continuum of the school's vertical discourse and are strongly linked to textbooks, as already noted. However, for pupils to appropriate the vertical discourse they must meet it in other semiotic resources as well.

\section{Analysing classroom space}

When analysing the classrooms and their affordances for teaching and learning, I have used a framework taken from linguistics: systemic functional linguistics (Halliday 1978; Halliday \& Matthiessen 1994). This framework has inspired much research in fields outside traditional linguistics, for example visual grammar in images and pictures (Kress \& Van Leeuwen 2009) and three-dimensional grammar in statues and museums (O’Toole 1994; Stenglin 2008), while Sofkova Hashemi (chapter 5 in this volume) has shown how social semiotics can be used to gauge pupils' multimodal meaning-making on-screen.

The starting point for systemic functional linguistics theory is that meaning is communicated through three metafunctions: the ideational metafunction (ideas about what is communicated), the textual metafunction (the form of the communication, for example, written text or speech or dialogue), and the interpersonal metafunction (how relationships are created and maintained). In this essay, I have chosen to use only part of the analytical framework for these metafunctions (Table 6.2). The framework used here is built on the work of a number of researchers who apply systemic functional linguistics theory to the study of three-dimensional space (Kress \& Van Leeuwen 2009; Van Leeuwen 2005; O’Toole 1994; Stenglin 2004; Ravelli 2008).

Classrooms typically foreground certain artefacts associated with the subject being taught. Fume cupboards and other visible science equipment communicate the ideational meaning of 
Metafunction

\begin{tabular}{|c|c|c|}
\hline $\begin{array}{l}\text { Ideational metafunction } \\
\text { Analytical concept }\end{array}$ & Textual metafunction & Interpersonal metafunction \\
\hline \multicolumn{3}{|l|}{$\begin{array}{l}\text { Literal \& symbolic meaning } \\
\text { (O'Toole 1994) }\end{array}$} \\
\hline $\begin{array}{l}\text { Grounding (Kress \& Van Leeuwen } \\
\text { 2009) }\end{array}$ & Paths \& venues (Stenglin 2004) & \\
\hline Separation \& access (Ravelli 2008) & $\begin{array}{l}\text { Power \& social distance (Ravelli } \\
\text { 2008) }\end{array}$ & \\
\hline \multicolumn{3}{|l|}{ Questions to the classrooms } \\
\hline $\begin{array}{l}\text { What is the literal idea of the class- } \\
\text { room (presented in for example, } \\
\text { activities and foregrounded arte- } \\
\text { facts)? What is the symbolic mea- } \\
\text { ning of the classroom? }\end{array}$ & $\begin{array}{l}\text { What flow or movements are } \\
\text { possible in the space and do } \\
\text { all participants have access to } \\
\text { all spaces? What is the reading } \\
\text { path? What venues (where } \\
\text { activities take place) and paths } \\
\text { (between these venues) are } \\
\text { there? }\end{array}$ & $\begin{array}{l}\text { What relationships between } \\
\text { participants are created and } \\
\text { maintained through how the } \\
\text { space is designed and furnished? }\end{array}$ \\
\hline
\end{tabular}

Table 6.2. Analytical framework.

a science classroom (the literal meaning). Seating arrangements, for example around circular tables, add to the ideational meaning of a pupil-centred classroom (the symbolic meaning). The textual meaning involves the paths and venues of the classroom, and pupils' and teachers' access to these venues. Pupils might be free to move about and help themselves to equipment and books for their work, or equipment may be stored out of reach, which means different levels of separation or access. Furthermore, classrooms communicate meaning regarding how interaction is meant to take place. This is the interpersonal meaning-how relationships are created and maintained. Power relations can be displayed using a separate teacher platform or the way in which pupils' desks are arranged. Different affordances for how teaching and learning are realised follow from the different meanings communicated in the design.

Five classrooms were studied (Fig. 6.2). Two, classrooms A and B, were dedicated classrooms for home and consumer studies. Classroom B was shared by two teachers. Two classrooms were biology classrooms, C and D, and one classroom was a chemistry classroom, E. The classrooms were fairly similar. In the following sections, I will present my analysis of the classroom designs and the affordances 


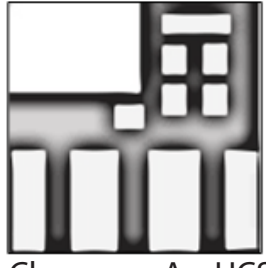

Classroom A - HCS

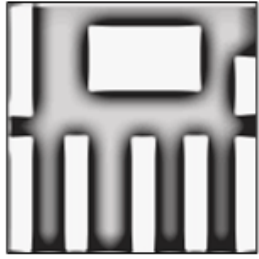

Classroom B - HCS

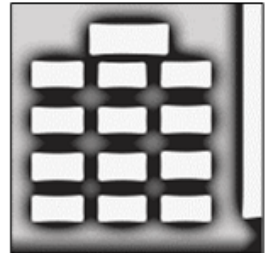

Classroom C - Biology

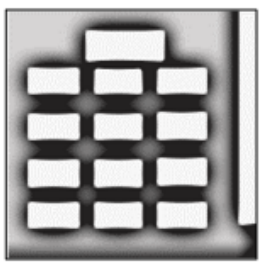

Classroom D - Biology

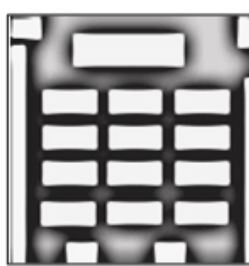

Classroom E - Chemistry

Figure 6.2. Schematics of the five classrooms studied.

for teaching and learning in these designs, based on observations of classrooms without participants, the use of the classrooms, and the occurrence of subject-specific language.

\section{The ideational classroom}

All of the studied classrooms had strong identities. Subject-specific artefacts such as fume cupboards, stuffed animals, or cookers were foregrounded. These literal meanings convey to the pupils, firstly, which subject is in focus and, secondly, what within the subject is prioritised, depending on the artefacts on display on the teacher's desk or side tables. The teachers would prepare equipment for experiments, talks, or cooking so that when the pupils arrived they might be met by a skeleton at the front of the classroom or a cart with solutions and equipment for a chemistry experiment. These artefacts constructed a literal ideational meaning that stressed the subject, the lesson's content, and what was expected of the pupils during lessons. In the cases of HCS and chemistry, the presence of the pupil kitchens and lab equipment constructs HCS and chemistry as practical subjects. Thus, when teachers chose not to use the kitchens for baking or 
not to use the fume cupboards, they worked against the ideational meaning of the classrooms. All classrooms expressed activities such as scientific investigations and household activities as part of the ideational meaning, which is in alignment with the syllabuses.

As regards the symbolic meaning, one of the HCS classrooms (Classroom A) stood out in its ideational design. It made use of its wall space for posters and newspaper clippings that related to HCS work in the classroom, but with an everyday angle, which is also part of the syllabus. In addition, cookbooks in this classroom were both representations of HCS textbooks from past to present and coffee-table cookbooks from high-street bookshops. The symbolic meaning in Classroom A was interpreted as constructing a subject relevant to both home and school. In comparison, the other classrooms were bare or minimalist; there were no permanent installations that showed, for example, how biology or chemistry were relevant to what goes on outside school.

In all classrooms, interaction was concerned with the subject in focus, as was the classroom design. However, Classroom A, by its symbolic ideational meaning, also invited input from the world outside school, from teachers and pupils alike. Pupils' own experiences were introduced by the pupils during whole-class sessions and during pupil work in kitchens. In the other classrooms, experiences from life outside school were introduced by the teachers. From the analytical perspective of the ideational metafunctions of a classroom, the language practices there were in harmony with both literal and symbolic ideational meanings. Communication centred on the subjects; both pupil and teacher interaction focused on either content or activities. Pupils knew when they walked into these classrooms what to expect of the lesson, and what was expected of them from the subject-specific and lesson-specific artefacts.

\section{The textual classroom}

The five classrooms all had two distinct venues where teaching and learning activities took place: the teacher venue at the front by the whiteboard or teacher's desk, and the pupil venue, where the 


\begin{tabular}{lll} 
Example & Venue & Communicative pattern and examples \\
\hline 1 & Teacher venue & Teacher IRF \\
& Okay. So what is this? 'Liquid ingredients'-it's a word, a term \\
& you use when baking. And when it says in the recipe that the \\
& liquid ingredients should be a certain temperature. What is it \\
& that needs to be a certain temperature? \\
& Participatory exchange \\
& S1: Hey, teacher. This is? \\
& T: Mm, has S2 felt it too? \\
& S2: What? \\
& T: Do this now [demonstrates] and keep your finger in it for a \\
& while. How does it feel? \\
S2: A bit warm.
\end{tabular}

Table 6.3. Example of interaction 1: Home and consumer studies: Classroom B. Italics=subject specific concept (liquid ingredients) and 2: italics= reference to subject specific concept (e.g. pronouns).

pupils sat during whole-class activities led by the teacher. The HCS classrooms (A and B) had one additional venue, the pupil kitchen venue. Here pupils mainly cooked and at times also carried out other group work. These venues were all clearly defined, as were the activities. In Classroom B (HCS), the teacher venue was connected to the pupil venue, as there was no teacher's desk. However, there was an understood boundary between these venues, as the teacher alone had access to the whiteboard and the pupils left extra space for the teacher to put files and other paperwork on the shared table space. Throughout all the lessons, the teacher venue was a restricted space for pupils. They rarely entered it, and instead approached the teachers during activities when the teachers were in the pupil venues.

Pupils and teachers had access to the pupil venues and pupil kitchen venues during activities such as experiments and group work. During teacher-led activities such as lectures or homework follow-up, however, pupils were expected to stay in their seats, and access to other venues was restricted. These differences in access were also realised in language practices. Teacher-pupil interaction during teacher-led activities led from the teacher venue was characterised mainly by teacher monologues or teacher IRF and subject-specific language, in contrast to the context-embedded participatory exchanges during cooking and lab 
work. These differences can be explained by the change in physical distance between participants, as well as the change in location, for example, from the description of an activity on the whiteboard or in the book to its execution at the desk or in the kitchen.

The examples from the HCS classrooms illustrate the change in interaction between venues (Table 6.3). Example 1, from the teacher venue, demonstrates the use of subject-specific language. It introduces a central term and concept for baking with yeast: liquid ingredients. Example 2 shows how communication in the pupil venues regarding liquid ingredients was realised, and specifically how context and place make subject-specific language redundant. However, if a concept is an essential one, it should also be made part of the context-embedded language used between teachers and pupils.

One noteworthy difference between classrooms A and B was in the designs of the pupil kitchen venues. In Classroom B, the pupil kitchens were separated by a wall, making all kitchens into individual units with no visual outlook on the others, apart from one space where two groups of pupils could work back to back. This design emphasised the ideational meaning of the classroom as a school subject classroom, to the extent that it appeared like a test station where the teachers could observe all pupils from a distance. During the examination lesson, pupils could feel that they were being observed, but they did not know if the teacher was observing them or somebody else (the notion of the panopticon). The separated spaces also restricted communication to the designated partner, thus pupils did not share experiences or thoughts with pupils in other kitchens while they were cooking.

In the other HCS classroom, there was more openness. The pupil kitchens were open between the overhanging cupboards so pupils could see what someone else was doing without leaving their kitchen. This meant that there would always be between four and six pupils who could communicate about their progress, their experiences or questions. Furthermore, the teacher could not observe from a distance. The classroom space and furniture arrangement required the teacher to approach the pupil kitchen venue in order to follow and assess the pupils' work. 


\section{The interpersonal classroom}

The classrooms studied here were unmistakable in their interpersonal meaning. From when they entered the classrooms, pupils knew how interaction should play out. Classroom A (HCS) had a pupil-centred arrangement in the pupil venue. Here, pupils were seated in groups of four, which was more reminiscent of seating arrangements at home or in restaurants. The two biology classrooms ( $\mathrm{C}$ and $\mathrm{D})$ had pupil desks arranged in pairs facing the teacher venue at the front. In Classroom $\mathrm{C}$, the teacher led interaction from the front, not necessarily from behind the desk, but moving between the whiteboard to the desk and the first pair of pupil desks, from where the teacher asked questions and pupils responded or worked at the desks either individually or with their neighbour. In Classroom D, the desk arrangement did not quite fit the teacher-pupil interaction that actually took place. The teacher moved around in the front part of the classroom, making little use of the whiteboard, and instead making use of his own body and the bodies of pupils and the artefacts brought into the classroom. It was a very talkative class where the teacher spoke most, introducing the biology content and then exemplifying this using the pupils' own experiences. Similar to Example 2 given earlier, interaction was characterised mainly by context-embedded, biology-related content in everyday language, and very little subject-specific language was in evidence. As most communication was spoken, with the aid of illustrative artefacts, it would have made more sense if the classroom had been arranged with the desks in a circle so the teacher could more easily show the artefacts and move around, and so the pupils could see one another when they interacted.

The chemistry classroom (Classroom E) had a clear synthesis of design and communication. Communication was led by the teacher from the lectern, which was raised so that pupils on the back benches could see demonstrations of experiments and so on. During lab work, the communication was between pupils at their desks, in groups of two or three. The organisation of teaching and learning activities was clear to the pupils, as was who had control of the communication. Each lesson followed a distinct pattern, which also corresponded to 


\begin{tabular}{|c|c|c|}
\hline Example & Venue & Communicative pattern and examples \\
\hline \multirow[t]{6}{*}{3} & Teacher venue & Teacher IRF \\
\hline & & T: If a solution has $\mathrm{pH}_{2}$, is it an acid or a base or is it perhaps neutral? $\mathrm{S}_{3}$ ? \\
\hline & & S3: Acid \\
\hline & & $\begin{array}{l}\text { T: It's an acid, yes. If the pH is } 13 \text { what solution is it then? Is it an acid, } \\
\text { base, or neutral? Yes, S4. }\end{array}$ \\
\hline & & S4: A base. \\
\hline & & $\mathrm{T}$ : It is a base. And what is the $\mathrm{pH}$ value for neutrals? \\
\hline
\end{tabular}

Table 6.4. Example of interaction 3. Chemistry.

the ideational meaning of the classroom design: chemistry equals experiments. The interactional pattern when not experimenting was a traditional triad of teacher initiation, pupil response and teacher feedback (Table 6.4). IRF patterns of this type do not allow for pupils to formulate answers using subject-specific language; it is IRF with the purpose of checking up on homework or whether pupils understand concepts, instead of allowing linguistic socialisation.

The distinct venues in all the classrooms, with their corresponding interactional patterns, reflect the social relations created by designs that put teachers in power in the classrooms, particularly in the teacher venues. Also, when the teachers moved around in the pupil venues in order to help or supervise work, the social distance was maintained, as pupils were seated and teachers were walking or standing. On occasion, teachers would approach pupils on a more equal level, by bending down or crouching. These moves on the teachers' part resulted in more private interaction in which power was still with the teacher, but the social distance was reduced. In these exchanges (participatory exchanges) there was subject-specific language, while everyday language was used to explain or elaborate on pupils' questions. Similarly, interaction was context-embedded and social distance was reduced in the HCS Classroom A with the open pupil kitchens. Here pupils were near one another, and the design also encouraged or required the teacher to reduce social distance as well, in contrast to when pupils were seated in the HCS classrooms. The simple fact that everyone was standing up and communicating at eye level in the pupil kitchen venues served to reduce the teacher's power status. 


\section{Conclusion}

School classrooms are versions of contemporary society, and norms and regulations are presented in their design and use. In the classroom, this is realised through artefacts that regulate behaviour and access, such as desks and chairs, signs, and locked or unlocked doors (see for example Dahlberg \& Åsén 2012; Eriksson Bergström 2013; Hipkiss 2014; Ravelli 2008). Similarly, classrooms are coded for certain activities, and these codings affect how classrooms are defined (Dahlberg \& Åsén 2012). In this study, all five classrooms have strong identities, due to subject-specific artefacts that are foregrounded in the classroom.

This study of the design of classrooms and interaction shows that classrooms have different affordances for teaching and learning activities. The classrooms create participating or listening pupils, depending on the venue in which interaction is lead-whether it is lead from the teacher venue or in the pupil venues. In addition, the designs influence pupils' opportunities for sharing experiences and knowledge. Lecture-like seating or seating that creates a distance between participants necessarily restricts pupils' opportunities for participation. The distance requires teachers to moderate their communication so that it is inclusive, inviting pupils in. As noted earlier (for example, Selander \& Kress 2010, 42) and in the results from this classroom study, classroom designs affect social relations, and different designs provide different affordances. Classrooms create meaning for interaction and shared experiences. The five classrooms presented here are examples of classrooms that provide a range of affordances for sharing experiences and interacting. Ideational meanings that put the subject in focus are dominant in both design and content, and the ideational meaning of classrooms as rooms for activities such as lab work or cooking is also prevalent-and understood from the designs. Pupils are schooled into a teacher-pupil relationship that presents the teacher at the lectern as the one who controls interaction, as the desks face forwards in all but one classroom. A lecture hall has its given mode of communication: the lecturer speaks, the audience listens, and asks questions if invited to do so. A classroom 
with desks in pairs facing the whiteboard and the teacher's lectern tells us that focus is on the teacher, who thus controls communication, while pupils are limited to communicating with their desk partners or the teacher. In addition, the design affects the language practices on a local level, within the interactional patterns.

Communication is an essential part of teaching and learning. How this communication is best enacted can be explicit from the design of a classroom, as this essay has illustrated. Communication led from the teacher venue, by the teacher, was prominent (93/128 phases) and typically identified as teacher IRF or a teacher monologue. In order for pupils to develop their use of subject-specific language or the vertical discourse of the school and to build knowledge cumulatively, they need to be able to use subject-specific language in different situations. In the lessons studied here, interaction offered few opportunities for pupils to do this, as teachers and textbooks provided the subject-specific input.

What is in a classroom, how it is used and altered, affects the affordances for teaching and learning, as do the activities and communication (Hipkiss 2014). Kress et al. (2001) describe teaching and meaning-making as materialisations of motivated choices that pupils and teachers make with regard to different semiotic resources, such as artefacts and interaction in the classroom. Thus, how a classroom is designed and used ought to be part of what we include when preparing and planning for teaching and learning activities. A classroom is a space which is organized and given meaning in interaction with humans' (Pennycook 2010:7) and the language practices in the classroom are constructed and reconstructed as a result of the affordances of these spaces. This means that when planning activities, teachers have to consider the arrangement of furniture and pupils. If the purpose is to 'show and tell' and to include pupils in the activity, the language practice will, or should, move between the abstract subject-specific textbook terminology and actual, context-embedded pupil experiences and artefacts in the classroom, leaving language practices to oscillate between the everyday and the abstract (Hipkiss 2014; Maton 2014). 


\section{References}

Bernstein, B. (1999), 'Vertical and Horizontal Discourse: An Essay', British Journal of Sociology of Education, 20/2, 157-73.

Björklid, P. (2005), Lärande om fysisk miljö: En kunskapsöversikt om samspelet mellan lärande och fysisk miljö i förskola och skola (Forskning i focus, 25; Stockholm: Myndigheten för skolutveckling).

Christie, F. (1995), 'Pedagogic Discourse in the Primary school', Linguistics \& Education, 7/3, 221-42.

- (2005), Classroom Discourse Analysis: A Functional Perspective (London: Continuum) (first pub. 2002).

Dahlberg, G. \& G. Åsén (2012), 'Loris Malaguzzi och den pedagogiska filosofin i Reggio Emilia', in A. Forsell (ed.), Boken om pedagogerna (Stockholm: Liber).

Davidsson, B. (2005), 'Klassrum, lekrum och andra rum: Om rum för lärande i integrerade verksamheter', Didaktisk tidskrift, 15/1-2, 51-63.

Elm Fristorp, A. (2012), Design för lärande: Barns meningsskapande i naturvetenskap (diss., Stockholm: Stockholm University).

Eriksson Bergström, S. (2013), Rum, barn och pedagoger: Om möjligheter och begränsningar i förskolans fysiska miljö (diss., Umeå: Umeå University).

Gibbons, P. (2006), Bridging Discourses in the ESL classroom: Students, Teachers and Researchers (London: Continuum).

Granly, A. \& E. Maagerø (2012), 'Multimodal Texts in Kindergarten Rooms', Education Inquiry, 3/3, 371-86.

Halliday, M.A.K. \& C. Matthiessen (2004), 'An Introduction to Functional Grammar (3rd edn, London: Hodder Education).

Hipkiss, A. M. (2014), The Semiotic Resources of the Classroom: An Applied Linguistics Perspective on the School Subjects Home and Consumer Studies, Biology and Chemistry (diss., Umeå: Umeå University).

Jewitt, C. (2005), 'Classrooms and the Design of Pedagogic Discourse: A Multimodal Approach', Culture \& Psychology, 11/3, 309-320.

Jones, P. (2008), 'The Interplay of Discourse, Place and Space in Pedagogic Relations', in Unsworth 2008.

Kilhamn, C., Rystedt, E., Nyman, R. \& Holmberg, B. (2019), The contribution of video studies to classroom research: seeking hidden dimensions of teaching and learning in algebra. In Osbeck, C., Ingerman, Å. \& Claesson, S. (eds.). Didactic classroom studies: A potential research direction. Lund: Nordic Academic Press.

Kress, G. (1993), 'Against Arbitrariness: The Social Production of the Sign as a Foundational Issue in Critical Discourse Analysis', Discourse \& Society, 4/2, 169-91.

- - C. Jewitt, J. Ogbord \& C. Tsatsarelis (2001), Multimodal Teaching and 
Learning: The Rhetorics of the Science Classroom (London: Continuum).

- - \& T. van Leeuwen (2006), Reading Images: The Grammar of Visual Design (London: Routledge) (first pub. 1996).

- - \& C. Sidiropoulou (2008), 'Klassrumsdesign', in A.-L. Rostvall \& S. Selander (eds.), Design för lärande (Stockholm: Norstedts Akademiska Förlag).

Lim, F. V. (2011), 'A Systemic Functional Multimodal Discourse Analysis Approach to Pedagogic Discourse' (diss., Singapore: University of Singapore). - - K. L. O'Halloran \& A. Podlasov (2012), 'Spatial Pedagogy: Mapping Meanings in the Use of Classroom Space', Cambridge Journal of Education, $42 / 2,235-51$.

Macnaught, L., K. Maton, R. J. Martin \& M. E. Matruglio (2013), 'Jointly constructing semantic waves: Implications for teacher training', Linguistics \& Education, 24/1, 50-63.

Martin, J. (2013), 'Embedded literacy: Knowledge as meaning', Linguistics \& Education, 24/1, 23-37.

Martin, J. R. \& Rose, D. (2008), Genre Relations (London: Equinox).

Maton, K. (2013), Making semantic waves: A key to cumulative knowledge-building. Linguistics and Education. 24 (2013). 8-22.

Maton, K. (2014), Knowledge and Knowers: Towards a Realist Sociology of Education (London: Routledge).

Matruglio, E., K. Maton \& J. R. Martin (2013)), 'Time travel: The role of temporality in enabling semantic waves in secondary education', Linguistics \& Education, 24, 38-49.

O’Toole, M. (1994), The Language of Displayed Art (London: Leicester University Press).

Pennycook, A. (2010), Language as A Local Practice (London: Routledge).

Ravelli, L. J. (2008), 'Analysing Space: Adapting and Extending Multimodal Frameworks', in Unsworth 2008.

Schleppegrell, M. J. (2004), The Language of Schooling: A Functional Linguistics Perspective (Mahwah, NJ: Lawrence Erlbaum).

Selander, D. \& G. Kress (2010), Design för lärande: Ett multimodalt perspektiv (Stockholm: Norstedts).

Stenglin, M. (2004), 'Packaging Curiosities: Towards a Grammar of Three-dimensional space' (diss., Sydney: University of Sydney).

Stenglin, M. (2008), 'Interpersonal Meaning in 3 D space: How a Bonding Icon Gets Its "Charge", in Unsworth 2008.

Unsworth, L. (ed.), Multimodal Semiotics: Functional Analysis in Contexts of Education (London: Continuum).

van Leeuwen, T. (2005), Introducing Social Semiotics (London: Routledge).

- (2008), 'Space in Discourse', in Unsworth 2008. 
Woolner, P. (2015), 'Introduction: A school environment to help, not hinder: Understanding the role of physical space in education', in P. Woolner (ed.), School design together (London: Routledge). 